\title{
Could Isidore's Chronicle Have Delighted Cicero? Using the Concept of Genre to Compare Ancient and Medieval Chronicles
}

\author{
Jesse W. Torgerson*
}

Richard W. Burgess and Michael Kulikowski's A Historical Introduction to the Chronicle Genre from its Origins to the High Middle Ages (Volume I in the authors' planned series Mosaics of Time: The Latin Chronicle Traditions from the First Century BC to the Sixth Century AD) posits that medieval studies has neglected to engage in a systematic, historically-informed reflection on the genre of chronicles. The present article asserts that this challenge to the field presents a unique opportunity for an interdisciplinary discussion of wide scope and lasting duration. I thus argue that Burgess and Kulikowski's larger points may be reconciled with current scholarship on medieval chronicles by updating the theoretical premises that underlie our identification of historical genres. I aim to contribute to the discussion by turning to a consensus in current theoretical work, that genre is best discussed as a description of the way texts and their readers communicated. The article concludes by applying this hypothesis to an experiment in comparison: if it is not the differences but the similarities that stand out when Cicero and Isidore of Seville's respective meditations upon chronicles are set side by side, then what are the implications for our methods of reconstructing the significance of chronicles in their own milieus?

Keywords: chronicle; history; Isidore of Seville; Cicero; genre

\section{Preface: a question}

In this article I would like to pursue a question in dialogue with a recent publication. The publication is Richard W. Burgess and Michael Kulikowski's A Historical Introduction to the Chronicle Genre from its Origins to the High Middle Ages, volume 1 of an intended four-volume series: Mosaics of Time: The Latin Chronicle Traditions from the First Century BC to the Sixth Century AD. My question is the following. There seems to be a growing consensus that medieval chronicles were and did something unique, something that is not captured by reading them as a period in the history of history-writing. To date, Burgess and Kulikowski's work goes furthest in offering this desired deep history of chronicle-writing in se. And yet, Burgess and Kulikowski intentionally frame their work in an antithetical relationship to medievalists' accounts of medieval chronicles and annals. Granting this: can Richard W. Burgess and Michael Kulikowski's Historical Introduction to the Chronicle Genre nevertheless provide a productive point from which scholars of the early Middle Ages could better explicate the "medieval chronicle genre« on its own terms? Is it possible to establish a productive consensus between recent work on medieval chronicles, and Burgess and Kulikowski's thesis?

* Correspondence details: Jesse W. Torgerson, College of Letters, 41 Wyllys Ave., Wesleyan University, Middletown, CT, 06457, U.S.A., email: jtorgerson@wesleyan.edu 


\section{Why we need an account of the shronicle genrer}

As regards historical writings, while medievalists have indeed sought to disassociate schronicler from shistory<, the Middle Ages remain that period which saw the dominance of the medieval version of history-writing - chronicles - over proper histories. Medievalists do assert and remind each other that chronicles are not histories. Nevertheless, without a clear articulation of what chronicles $\mathrm{did}$, even we struggle to apply the principle, still finding ourselves in tautological discussions that begin and end with the notion that chronicles really are not very good histories, and still fighting the looming spectre of anachronism: why did the Middle Ages not do things better?

There is no question that important studies have been marching us steadily towards better appreciation and understanding of late antique or early medieval Latin and Greek chronicles in se. However, chronicles primarily receive resuscitation on an individual basis, one-at-atime. Our improved readings have not yet written out how we might disentangle chronicles, as a body of literature, from the history of histories. We need a method of reading that crosses the late antique and early medieval, crosses between east and west, and provides us with a good notion of what it is - what it is exactly - that chronicles, as a genre, do and did with time, at different times. How did chronicles make meaning? It is with this perspective that I turn to A Historical Introduction to the Chronicle Genre for a coherent "chronicle genre" distinct from the history of history-writing, for chronicles not as An (unfortunate) Way Medievals Wrote History, but as nothing more nor less than chronicles.

\section{How now, an answer? The argument of a historical introduction to the chronicle genre}

A Historical Introduction to the Chronicle Genre certainly moves the discussion towards this end. Richard W. Burgess and Michael Kulikowski (hereafter RB and MK) insist that chronicles are unique, meaningful, have a long and very respectable literary pedigree, and as a genre, a socio-political role in their communities. RB and MK's treatment of chronicles crosses both the east-west (i.e., Latin-Greek) and the ancient-medieval divides. They challenge medievalists to take into account the ancient formulation of the genre, and challenge classicists to both accord the genre its place in classical literature, and to more fully account for ancient chronicles' medieval afterlives and transmission:

The first Latin chronicles, as we have seen, were the product of Rome's highest intellectual circles. They were written, read, and enjoyed by the intellectual and literary giants of the time. ... Chronicles were not to be judged against Livy or Tacitus, nor even against Florus or Eutropius, and we ought not to do so either. Chronicles are what they are, and must be judged on that basis, not in comparison with anything else. ${ }^{1}$

$\mathrm{RB}$ and MK equip scholars to see people in the ancient world - literati as well as hoi polloi - appreciating chronicles for what they were. On what exact terms, then, do RB and MK define the specific "job « that chronicles were "meant to do«?

The title of RB and MK's planned series of volumes is Mosaics of Time: The Latin Chronicle Traditions from the First Century BC to the Sixth Century AD, while the single volume under consideration here is: A Historical Introduction to the Chronicle Genre from its Origins to the High Middle Ages. Thus RB and MK's historical account does not focus on "Latin Chronicle

1 Burgess and Kulikowski, Historical Introduction, 274. RB and MK repeatedly bring this point before their fellow classicists with lines such as: "If one of Rome's greatest minds [Cicero] could delight in a chronicle, there is no reason why we cannot as well«, ibid., 7, and see 94 .

2 "The chronicle survived as a genre for thousands of years... it had evolved perfectly to do the job it was meant to do«, Burgess and Kulikowski, Historical Introduction, 274. 
Traditions « but on "The Chronicle Genre«. Accordingly, Chapter One (»Early Chronicles«) establishes the genre shistorically«, meaning the first texts that constitute proper, or true, chronicles are identified in time and place, and their characteristics constitute RB and MK's definition of the genre ex origines. The phrase that RB and MK most often use to distinguish texts with these proper (or full) characteristics is >True or >Ancient Greek Chronicles. ${ }^{3}$

After Chapter One, the argumentative thrust of A Historical Introduction to the Chronicle Genre takes a pause, only to be truly resumed in Chapter Six. ${ }^{4}$ There is a unique common purpose binding the first and the last chapter; if Chapter One establishes where we can historically identify and so define chronicles, then Chapter Six uses this definition to determine the limits: where and when did the Ancient Chronicle cease to be ${ }^{5}$ Chapter Six answers: the sixth century was the last time a >Trues, sAncient Greek chronicle would be produced in the Greco-Latin Mediterranean-European world (John of Biclar and Victor of Tunnuna represent the end point). And so the shocking conclusion is drawn: 'medievalk works regularly regarded as chronicles - the Latin Chronica of Isidore of Seville and the De Temporum Ratione of Bede, or the Greek Chronographia of George Synkellos and Chronicon of Theophanes the Confessor - presented events framed by time, but were not truly chronicles.

$\mathrm{RB}$ and $\mathrm{MK}$ arrive at this stringent assertion by sorting out a definitive nomenclature, and applying it. For a chronicle to be a chronicle, there must be a "chronographic framework " organizing the text; ${ }^{6}$ the content must also have a certain minimalist aesthetic or "paratactic style «; ${ }^{7}$ and finally, there is the internal logic of the content, wherein "causal relations are generally absent, individual entries related to one another by (using Barthes' distinction) consécution not conséquence. ${ }^{8}$ For $\mathrm{RB}$ and $\mathrm{MK}$, all of this is encapsulated in a Ciceronian quotation, with which they begin and end their volume. I will engage with this passage below, but for now: A Historical Introduction to the Chronicle Genre emphasizes that Cicero delighted in a chronicle because there he found the past in uno conspectu, as "at a glance."

3 It is essential to note the "Ecumenical Vocabulary« in the "Addendum« to the sixty-page argument of Chapter 1, Burgess and Kulikowski, Historical Introduction, 59-62. RB and MK rely on this terminology when they analyse any given work, and so readers interested in skipping to the discussion of a particular chronicle must keep a finger to this three-page summary of terms.

4 I describe the content of the book with an eye towards the over-arching argument. Readers interested in more detailed summaries should consult the reviews already available, an updated list of which is maintained on the Brepols website devoted to A Historical Introduction to the Chronicle Genre: http://www.brepols.net/Pages/ShowProduct.aspx?prod_id=IS-9782503531403-1 (retrieved 3 June 2016).

5 The authors begin the sixth chapter: "As we move to a discussion of the chronicle genre in the Middle Ages, it will be useful to remind the reader of our discussion of genre and nomenclature in Chapter 1«, Burgess and Kulikowski, Historical Introduction, 189. Over half of the core content of the book (142 out of $274 \mathrm{pp}$.) is contained in these two chapters.

6 " ... the chronographic framework ... the chronographic constraints ... the subordination of content to the chronographic framework [which] can be retained even where there is no content to report.« Burgess and Kulikowski, Historical Introduction, 190.

7 "[T]he brevity with which content is recorded is another key characteristic of the genre and tends to lead to a paratactic style that renders it difficult or impossible to distinguish the relative importance of any individual item of content or the relationship (if any) of one entry (or rannals) to another." Burgess and Kulikowski, Historical Introduction, 190.

8 Burgess and Kulikowski, Historical Introduction, 190, and see 23. 
If we turn back to Chapters Two through Five, we might note their role in this thesis, elucidating the way that Roman society under the Principate and Early Empire came to express Ciceronian delight in chronicle-like approaches to knowledge of the past by producing chronicleesque spin-off genres such as consularia, calendars, and slocal chronicles. ${ }^{9} \mathrm{RB}$ and MK synthesize this material to argue that the composing of calendars and consularia relate to a chronicling impulse, an interest in seeing the past (even if it is only the recent, localized past) in uno conspectu.

In sum, I would distinguish two arguments made by RB and MK's Historical Introduction to the Chronicle Genre. The first is their new hypothesis: the chronicle genre had a continuous millennium of importance, and even influence, from ca. 5/400 BC: a much richer story than either ancient or medieval historical and literary scholars have heretofore acknowledged. This provocative longer history of chronicle-writing certainly convinces me that scholarship on the reading and writing of medieval chronicles has something to gain by considering how Demetrius of Phaleron, Phlegon of Tralles, and Atticus created and transmitted an ancient way of thinking. ${ }^{10}$

The second argument, however, challenges a premise held by medievalists in general. $\mathrm{RB}$ and MK insist that the set of characteristics scholars indicate with the term "chronicle" should not be defined by the (more numerous) medieval texts to which we might assign the title, but instead "chronicle « should be reserved for texts with the (more originary) ancient characteristics: post-seventh-century texts should not be entitled »chronicle«. The remainder of this essay engages with the terms of this sustained argument (as set out in Chapter One and applied in Chapter Six), by which the authors seek to identify exactly when the True or Ancient Greek Chronicle disappeared from Greek and Latin literature.

I argue, contra RB and MK, that we must not relinquish the smedieval chronicler. On the one hand, the idea is impractical. Only a terminological dictatorship could stop rannak and schronicle from being used to rather casually encompass a variety of historical writings across the millenium of the >Middle Ages (as in G. Dumphy's Encyclopedia of the Medieval Chronicle). On the other hand, one compelled by the spirit of RB and MK's argument for terminological sensitivity (as I am), could still extend the story of the chronicle-writing tradition through other means than raising up definitive ancient examples to the denigration of the medieval or Byzantine. ${ }^{11}$ I propose instead to adopt RB and MK's account of the ancient tradition, but to extract the premise that one set of specific characteristics, based on certain formative texts from the ancient (Greek-speaking) world, is what "chronicle « was. I propose to do this by challenging RB and MK's idea of genre, and by proposing an alternative to their reading of the key phrase in Cicero's Brutus - in uno conspectu.

9 Hence the reader will find these chapters' arguments - that chronicles provided a »democratization « of the past an enjoyable challenge to more standard histories of Latin Literature.

10 Understanding chronicles as "the only ancient literary genre that has a direct and continuous history from antiquity into the medieval era in both the Latin and the Greek worlds" (Burgess and Kulikowski, Historical Introduction, 189) implies "that the writing of history in the Middle Ages [should not be seen] as sui generis, but as a direct continuation of all that went before«, ibid., 35.

11 A Historical Introduction pushes so strongly against the widespread non-specific use of schronicler and rannal that RB and MK build from their previous call for scholars to stop calling annals, rannals`, to here insist that we should not call them schronicles either; see: Burgess and Kulikowski, Historical Introduction, 12-20; 189-190. I cannot agree with the authors on this point, but one should also consult the authors' earlier argument in Burgess and Kulikowski, Medieval Historiographical Terminology, especially 169-170. 
In uno conspectu: An alternative reading of Cicero's sdefinition of chronicle

$\mathrm{RB}$ and MK's A Historical Introduction to the Chronicle Genre establishes a paradigmatically non-classical, ımedievalk item - the chronicle - as a literary genre of the classical world, in no small part by drawing upon classical Latin's classic Latinist. Cicero left us a positive assessment of a chronicle, as a chronicle, most particularly in the summation of the prefatory discourse to his De claris oratoribus liber qui dicitur >Brutus . $^{12}$ To hone in on the core of Cicero's positive evaluation of a chronicle, RB and MK focus on a result clause at the end of a discussion in which the character Cicero explained his appreciation of Atticus' chronicle to Atticus and Brutus:

... ut explicatis ordinibus temporum uno in conspectu omnia uiderem. ${ }^{13}$

Cicero's statement is referred to throughout A Historical Introduction to the Chronicle Genre: it inspires the conclusion, and is the introductory epigraph, where the clause is translated in functional grammatical isolation:

I could see everything in chronological order at a single glance. ${ }^{14}$

$\mathrm{RB}$ and MK interpret Cicero's phrase as answering an implied question: what defines a chronicle as unique? The authors answer: a true chronicle exhibits the Ciceronian idea of "everything in chronological order at a single glance", by giving a reader "the ability to see history uno in conspectu. $\aleph^{15}$ Then from this premise comes the conclusion: "The purpose of the chronicle was to organize those memories and put everything in its proper chronological relationship to everything else. ${ }^{16}$ A Historical Introduction to the Chronicle Genre thus deploys phrases such as "organize everything" and "at a single glance" (in uno conspectu) as the True Chronicle Test for any prospective candidate for the genre.

Making it impossible for classicists to dismiss ancient chronicles, and encouraging medievalists to incorporate Cicero's analyses are desiderata, but to achieve these ends RB and MK have approached the passage from Brutus with a definition of genre whereby originary characteristics are definitive, and are the standards to which later works must aspire. That is, $\mathrm{RB}$ and MK's view holds a genre's ontology to be contingent (the schronicler has come into being), but maintains that the species can only ever slightly evolve before distinction becomes significant difference. This approach to genre maintains analytic clarity at the expense of preserving the terms authors and readers in the past chose for themselves. ${ }^{17}$ Before

12 De claris oratibus (composed ca. $46 \mathrm{BC}$ ) is a history of Roman oratory via dialogue in which Brutus and Atticus ask Cicero to describe orators' works up to their time, of course defending Cicero's own oeuvre along the way.

13 Cicero, Brutus, ed. Malcovati, 4.16-17.

14 Epigraph to Burgess and Kulikowski, Historical Introduction.

15 Burgess and Kulikowski, Historical Introduction, 93-94. "This Ciceronian idea of suno in conspectu<, then, lies at the very heart of what a chronicle is [...]. If it isn't brief, it isn't a chronicle«, ibid., 27.

16 Emphasis by the author. Burgess and Kulikowski, Historical Introduction, 25.

17 "[We] are not in any way claiming that anyone in antiquity used these [generic] terms in this way«, Burgess and Kulikowski, Historical Introduction, 9. See the authors' brief discussion on genre on pages 8-10. RB and MK do see chronicles characterized by a particular relationship between author, reader, and text (ibid., 23-25 or 33-34, where the titular metaphor of chronicles as "mosaics of time« is explored). Confusingly, between these two passages, RB and MK first state that all chronicle entries are "in conceptual isolation « while then later insisting on Hayden White's famous analysis in White, Value of Narrativity, that any lack of narrative or "plot " is merely apparent for chronicles "possess an overall- or 'macro-narrativer which is implicit in the totality of chronology, events, and individuals accumulated in a text.", Burgess and Kulikowski, Historical Introduction, 33. 
I offer a critique of RB and MK's use of Brutus in service of their approach to genre I would like to note that I intend for my critical discussion of this issue to detract in no way from the significance of RB and MK's work. I seek, rather, to pick up on the authors' stated goal: to provoke conversation. ${ }^{18}$

Turning to the already-mentioned passage from the beginning of Cicero's Brutus, we find that in context Cicero's character was not providing a literary taxonomy of »the chronicle«, but answering a specific question from Atticus about the effect of, specifically, his own chronicle. As the dialogue gets under way, we find the three friends in question - Cicero, Atticus, and Brutus -discussing the letters they had recently exchanged. Cicero soon turns his attention to the chronicle that Atticus sent with his letter. The interlocutor, Brutus, notes that Cicero had been mired in despair and asserts that the effect of Atticus' Chronicle upon Cicero - of delight (delectatio) - is unique. Cicero agrees but clarifies that the work was a delight insofar as it provided the restoration of his salus.

Istae vero, inquam, Brute, non modo delectationem mihi, sed etiam, ut spero, salutem adtulerunt. ${ }^{19}$

(Indeed, Brutus; I mean that those [writings] not only brought me delight, but also as I hoped - brought well-being.)

Reading Atticus' Chronicle brought about salus ('well-being`) by, as Cicero's dramatis persona states, lifting his spirits out of a particular kind of sickness - a political despondency, or a depression about the state of the Republic. This healing did indeed delight Cicero, but the point that the dialogue emphasizes is that Atticus' chronicle saved Cicero from his despair. ${ }^{20}$

Upon having his work so roundly praised, Atticus asked Cicero to explain these positive effects via a summative question, a rreading of the dialogue thus far.

... sed quid tandem habuit liber iste, quod tibi aut novum aut tanto usui posset esse? ?21 $^{21}$

(... but what could that book hold, that could possibly be to you either new, or so useful?)

Cicero could have refuted Atticus, and insisted upon the idea of >delight $\iota$, but instead he agreed with the author's supposition: newness and usefulness were the chronicle's significant attributes:

Ille vero et nova ... mihi quidem multa et eam utilitatem quam requirebam, ut explicatis ordinibus temporum uno in conspectu omnia viderem. ${ }^{22}$

(Indeed it certainly [provided] both many things new to me, and this use which I required: the order of times having been explicated, I could see all in one comprehensive view.)

18 RB and MK gave medievalists a preview of their thesis well in advance (Burgess and Kulikowski, History and Origin), and in Historical Introduction devote sincere passages towards inviting scholarly debate over the issues they raise as on page 8 , with another remarkable example of a truly conversation tone, page 10 . The book's structure makes good on this sentiment: the authors lay out their terminology and its rationale (ibid., 59-62) and are so concerned to expose their reasoning on key issues as to provide not only extensive appendices (ibid., 275-355), but an appendix to the footnotes (ibid., 357-382).

19 Cicero, Brutus, ed. Malcovati, 4.10-11.

20 Cicero used an exchange, in which Brutus sought to clarify which work they were discussing, to re-emphasize the point about his salus: ... dico librum mihi saluti fuisse (... I mean the book has been salvation for me), Cicero, Brutus, ed. Malcovati, 4.20-21.

21 Cicero, Brutus, ed. Malcovati, 4.13-14.

22 Cicero, Brutus, ed. Malcovati, 4.25-27. 
Here, then, is the phrase so important to RB and MK's generic history, but it follows Atticus' query as to whether the Chronicle had confronted Cicero with something new and useful. Cicero strongly affirmed the idea by retaining Atticus' binary structure in his response (his "et ... et « corresponds to Atticus' "aut ... aut«), verifying that the proposal was accurate: the chronicle had provided something new and useful, in restoring well-being. ${ }^{23}$

It seems inappropriate to excerpt a definition from any one portion of this exchange, or especially to neglect any of the effects that Cicero emphasized throughout the imagined discussion. ${ }^{24}$ Instead, I would sum up the dialogue's prognosis of the connection between Atticus' Chronicle and Cicero's mood as follows. Atticus' Chronicle presented everything in its ordained temporal place and in a single scope: a new way of seeing old information. This presentation proved useful, alleviating despondence over the state of the world; the experience of the cure brought delight.

Newness, well-being, delight, and usefulness: all had to do with each other, and all came into play in the encounter between one reader and Atticus' chronicle at a specific historical moment. Atticus had not asked what was snew or useful about chronicles in general, but what had been useful and new for Cicero. Cicero had needed a remedy that would lift his spirits, and the chronicle had conveyed just that: a new perspective on the world. For RB and MK, Cicero's »delight" derived from the ludic possibilities enabled by the chronicle's presentation of the past, a presentation which facilitated a kind of "play « with information; ${ }^{25}$ while not denying that this idea is present to a degree, in my reading (by contrast) Brutus emphasized how Atticus' Chronicle had directly and precisely matched a particular need, usefully saving Cicero from despair. The "delight « Cicero had experienced was not posited as a universal effect of seeing things in uno conspectu, but was linked with the experience of a pleasant remedy, or cure, for political malaise. Brutus presented Atticus' chronicle as a text that incited readers to rethink their world, to rethink time, to confront old things in a new light, to surprise, shock, even reveal.

My more ssubjectiver reading of Cicero's comments is rooted in an approach to genre that incorporates function and audience into its description. In what follows I would like to identify how my contextualized reading of the Brutus passage is in dialogue with a now well-established "turn " in genre theory concerned with ascertaining how texts work in dialogue with their readers. That is, current genre theory encourages us in the same direction as this reading of Brutus: the effect on particular readers in specific situations has to be a part of what makes any chronicle, a chronicle.

23 Brutus explicitly repeated the keyword - salutem - and asked Cicero to clarify. Cicero explained: An mihi potuit, inquam, esse aut gratior ulla salutatio aut ad hoc tempus aptior quam illius libri, quo me hic adfatus quasi iacentem excitavit? Cicero, Brutus, ed. Malcovati, 4.11-13.

24 Cicero's response and Atticus' summary come within a series of binary alternatives on the chronicle's effects: from salvation and delight, to welcome and seasonality, and finally to newness and use; I read these grammatical binaries as building up to the final clause of Cicero's response.

25 For RB and MK the chronicle's design allowed someone like Cicero to "visibly delight in hopscotching across the years«, Burgess and Kulikowski, Historical Introduction, 94. 


\section{Bringing Genre Theory to A History of the Chronicle Genre}

By drawing connections between an identifiable consensus in genre theory and my analysis of the passage from Cicero's Brutus, I hope to establish a way for RB and MK's larger thesis to re-interrogate the early medieval chronicles we thought we understood. In order to provide what I am calling a sconsensus in contemporary genre theory, I will survey four highly accessible works from the field of genre studies published in English over the last twenty years: Daniel Chandler's 1997 An Introduction to Genre Theory; David Duff's Modern Genre Theory (2000); John Frow's Genre: An Introduction (2005); and, Anis Bawarshi and Mary Jo Reiff's Genre: An Introduction to History, Theory, Research, and Pedagogy (2012). I limit myself to these introduction-level anglophone texts in order to illustrate that despite differences between these authors' interests (connecting semiotics and film; historicizing genre criticism; formulating genre as textual cues to readers; teaching genre as writing), they present a remarkably stable consensus from within the field on the parameters within which analysis of genre now takes place.

As applies to the topic at hand, Daniel Chandler's An Introduction to Genre Theory (1997, updated 2000), pointed out problems with the same straditional approach to genre which seems to characterize RB and MK's taxonomy of the chronicle. This "approach sees genres as strue in some sense, but in doing so it falls prey to the rempiricist's dilemma' «. ${ }^{26}$ The dilemma appears in A Historical Introduction to the Chronicle Genre when, in order to identify the characteristics of schronicles`, RB and MK isolate the texts that are chronicles on the basis of the characteristics that make them schronicles: these texts are chronicles, and schronicles are these texts.

Chandler's alternative approach points to Reader Response Theory: "if we are studying the way in which genre frames the reader's interpretation of a text then we would do well to focus on how readers identify genres rather than on theoretical distinctions. ${ }^{27}$ Chandler goes on to assert that not only must we incorporate the responses of readers when we discuss genre, readers must be the ones who ultimately define the genres. ${ }^{28}$ In other words: "one way of defining genres is as sa set of expectations «", which regulate the "desire, memory and expectation " of the reader. ${ }^{29}$ Thus, "genres are not simply features of texts, but are mediating frameworks between texts, makers and interpreters. $\aleph^{30}$ Chandler gives us ıgenre mic, oft-changing "intertextual concept «, ${ }^{31}$ a phenomenon of time and place which concerns readers' encounters with texts more than texts in se.

To understand how the field arrived at the idea that "genres need to be studied as historical phenomena, "we might turn to David Duff's collection Modern Genre Theory (2000). ${ }^{32}$ What Chandler criticized as a "traditionalist « approach, Duff more precisely labels a "formalist " or "taxonomic" approach to genre which saw an ontology in generic categories, and which subsumed textual items as either "members « or outliers of these generic categories. ${ }^{33}$

28 Pointing to the "Wittgenstein-ian« idea of "family resemblances« instead of definitional features, a move often attributed to Alistair Fowler, Kinds of Literature.

29 Chandler, Introduction, 8, 9.

30 Chandler, Introduction, 8.

31 Chandler, Introduction, 6.

32 Chandler, Introduction, 4.

33 Duff, Modern Genre Theory, 18. 
Duff's narrative depicts twentieth-century critics' deconstructions of this approach as conceptually building up to or emitting from the possibility (memorably expressed by Derrida's assertion that texts "participate " in genres) that, in the end, every text may be sui generis. ${ }^{34}$ One of Duff's illustrations of that process dwells upon Tzvetan Todorov's Genre as Discourse as a response to Maurice Blanchot's Le Livre à venir (1959). Blanchot had posited that "a book no longer belongs to a genre; every book stems from literature alone,${ }^{35}$ which Todorov glossed to mean: "there is no intermediate entity between the unique individual work and literature as a whole, the ultimate genre. $\aleph^{36}$ Todorov then pushed back, arguing that while "a genre, whether literary or not, is nothing other than codification of discursive properties", genre was still something. ${ }^{37}$ Todorov then pursued an idea which would become a part of the widely accepted premise I am positing we should incorporate: to the degree that they rexist ‘, genres are extant in the communicative relationship between readers and authors: "readers read in function of the generic system, with which they are familiar ... [though] they do not need to be conscious of this system. « $^{38}$

For Duff, genre theory - having absorbed the idea that genre should "serve« individual texts rather than govern them - has moved on from pure critique, "and a degree of consensus is beginning to emerge about both the possibilities and the limitations of the concept of genre. ${ }^{39}$ Duff sees his field carrying on with the idea that "genre« is best understood as a communicative act. Or, as the medievalist Hans Robert Jauss insisted in 1982: by "genre" we should mean "a preconstituted horizon of expectations" which was "ready at hand ... to orient the reader's (public's) understanding and to enable a qualifying reception. ${ }^{40}$ To identify genre means to describe exchanges between readers and texts in particular moments.

Building directly on the work of Gerard Genette, John Frow's 2005 piece Genre: An Introduction (in Routledge's "New Critical Idiom« series) contributes a useful discussion of genre as a description of how readers organize knowledge in these exchanges between reader and work. Frow's focus is on "generic cues" which evoke how "...the move from what is said to what is implied is shaped in particular ways by the social codes of genre « ${ }^{41}$ The reader understands or experiences genre "in terms of particular historical codifications of discursive properties. ${ }^{42}$ In all of this, there is an insistence on ongoing generic contingency: "the order formed between and among genres should be regarded as a historically changing system rather than as a logical order. $«^{43}$

34 Referring to Derrida's The Law of Genres, in Duff, Modern Genre Theory, 230; discussed by Duff on pages 5-6 and 14. See also the similar discussion in Bawarshi and Reiff, Genre, 20-22. The critical reactions are labelled variously by Duff as "post-romantic«, "structuralist«, "post-structuralist«, and »historical«.

35 Quoted by Todorov, Origin of Genres, in Duff, Modern Genre Theory, 195.

36 Todorov, Origin of Genres, in Duff, Modern Genre Theory, 194.

37 Todorov, Origin of Genres, in Duff, Modern Genre Theory, 198; the point is discussed further by Duff, Modern Genre Theory, 17-18.

38 Todorov, Origin of Genres, in Duff, Modern Genre Theory, 200; discussed by Duff, Modern Genre Theory, 18-19.

39 Duff, Modern Genre Theory, 15.

40 Jauss, Theory of Genres, in Duff, Modern Genre Theory, 131.

41 Frow, Genre, 80.

42 Frow, Genre, 71.

43 Frow, Genre, 70 and 71. That is: «[S]uch an approach makes it possible to bring together the categories of a poetics with those of the historical event: if genres are actual and contingent forms rather than necessary and essential forms, they are nevertheless not arbitrary«, ibid., 71. 
For our purposes, Anis Bawarshi and Mary Jo Reiff's 2012 work, Genre: An Introduction to History, Theory, Research, and Pedagogy, emphasizes agreement on this point amongst genre theorists. Bawarshi and Reiff's publication is a handbook on teaching writing through genre theory, an impossible proposition unless genre theory contains fairly stable content. In Bawarshi and Reiff's summation, genres emerge and respond to "socio-historically situated exigencies «: »texts do not belong to a genre, as in a taxonomic relation; texts participate in a genre, or more accurately, several genres at once. $\aleph^{44}$ To put it as colloquially as possible: "[Genres] function as conventionalized predictions or guesses readers make about texts«, which do change because they are categories which "we impute to texts. «45

In sum: over the course of the last half century, critical work on genre has come to hold that to describe genre is to identify the particular way texts and audiences worked with and upon each other to create and modify patterns of reading. This consensus is perhaps put most succinctly by Frow's assertion that »the mode of the existence of genres is social.« ${ }^{46}$ That is, genres are both "models of writing " for authors and the "horizon of expectations" for readers. Any account of genre must reckon with both sets of phenomena within the dialogic relationship between texts and readers. I hope it now seems plausible that Cicero's key in uno conspectu passage also points us in this same direction. We should extend the scope of what belongs within the chronicle genre beyond definitive characteristics, to a consideration of how Atticus' chronicle (for instance) made an impact by working both with and against Cicero's preconception of the genre. Let us now apply this hypothesis by proposing an alternative reading of the key turning point in RB and MK's Historical Introduction to the Chronicle Genre: Isidore of Seville's seventh-century Chronica.

\section{Why do RB and MK reject Isidore's Chronica as a chronicle?}

The Chronica of Isidore of Seville plays an important role in RB and MK's A Historical Introduction to the Chronicle Genre. ${ }^{47}$ The Chronica is the earliest work which RB and MK emphatically state is not a chronicle, but which is universally regarded as a chronicle by medievalists. As such RB and MK build their case for absolute differences between the "ancient chronicle» and the (chronicle-like) "medieval chronicle epitome« upon Isidore's Chronica. $\mathrm{RB}$ and MK grant that Isidore's work would pass a superficial test for a chronicle since it works with a chronology: the "chronology of the six ages of the world is fully incorporated into the working out of the text. ${ }^{48}$ However, for RB and MK, a chronology does not make a chronicle. ${ }^{49}$ Indeed, RB and MK's conclusion is anticipated in their description of the Chronica's chronology as a "chronology of the six ages". In RB and MK's reading, Isidore's summing up of all times (temporum summa) in Augustine's "six ages" chronology was a direct evocation of "divine planning «, an approach to time with an implicit narrative..$^{\circ}$ For RB and MK,

44 Bawarshi and Reiff, Genre, 16. As the authors go on to articulate, genre sexists to the act of communication between reader and text: "there is always a genre and genres, yet such participation never amounts to belonging «, ibid., 21.

45 Bawarshi and Reiff, Genre, 23, quoting (in part) from Frow, Genre.

46 Frow, Genre, 69.

47 Burgess and Kulikowski, Historical Introduction, 192-201.

48 Burgess and Kulikowski, Historical Introduction, 200.

49 "The presence of a chronology does not make a work a chronicle" even if "Isidore clearly believed that he was working within the ancient chronicling tradition«, Burgess and Kulikowski, Historical Introduction, 198.

50 Burgess and Kulikowski, Historical Introduction, 199. Isidore »invented a new type of chronicle... a new tradition of universal epitome«, ibid., 192. 
a text with an indelibly >Christian « chronological structure, could not be an ancient Greek chronicle. ${ }^{51} \mathrm{RB}$ and MK thus accuse Isidore's Chronica of not standing on the order of time alone, but of being governed by a narrative of connected events. ${ }^{52}$

It is not clear to me that RB and MK are entirely even-handed with their insistence that a >Christian s plot undermines reading Isidore's Chronica as a chronicle. RB and MK posit early on that their »ecumenical« approach to chronicles applies an »ecumenical vocabulary « to »five stages in the development of the chronicle«, from "Near Eastern« through "Medieval. «53 Nevertheless, in contrast to the rest of these "stages «, it is only the "Medieval« that could not produce any real chronicle, but managed only the "chronicle epitome. "This is despite the fact that $\mathrm{RB}$ and MK make concessions to the possibility of particular works »bending " genre while still remaining a chronicle. ${ }^{54}$ It is also despite the fact that the argument for Isidore's Chronica being "a new type of chronicle" requiring a new generic label (»chronicle epitome«) relies on seeing Isidore's use of »Augustine's theory of the six ages of the world« as importing the foreign substance of narrative into chronography, even though RB and MK had earlier conceded (following Hayden White) that any chronicle must have some kind of "plot", an "overall or smacro-narrativer. ${ }^{55}$ Isidore went just too far, his Chronica »more visibly evocative of divine planning than was the succession of human empires that had structured the work of Eusebius-Jerome. $\aleph^{56}$

If there is a real difference here, it is very subtle. It is so subtle that it is not at all clear to me that this analysis reflects the logic of the Chronica's use of the "six ages", nor that it successfully captures the ability of the Chronica to subtly (rather than overtly) guide its readers into particular insights about the reckoning of time in se- a characteristic which at one point RB and MK convincingly insist is what makes a chronicle a chronicle, and which I have proposed must be emphasized as a more sure signal of the genre. ${ }^{57}$ Finally, reading Isidore's Chronica as being more governed by a narrative of time's progress than by time itself contradicts the evidence we have from Isidore's own reading of the Chronica in his Etymologiae. ${ }^{58}$ In what follows, I look to propose an early medieval »reading " of Isidore's Chronica by approaching Isidore's Etymologiae, not as a version, but as a reading of the Chronica. ${ }^{59}$

51 See Historical Introduction, 34-35 on this >Christian` perspective.

52 "Isidore's linear structure shows time moving along a single axis, rather than the multiple axes of the early sections of Eusebius-Jerome«, ibid., 200.

53 Burgess and Kulikowski, Historical Introduction, 18-19.

54 See the discussion of Cassiodorus' Consularia exhibiting enough characteristics of both »chronicle« and »consularia" to be both at the same time on Burgess and Kulikowski, Historical Introduction, 42-43 and 58.

55 Burgess and Kulikowski, Historical Introduction, 199 and 33.

56 Burgess and Kulikowski, Historical Introduction, 199-200. Emphasis by the author. Isidore's ideology was "rather more Byzantine and medieval« than Eusebius' Chronological Canons with »an emphasis on the majesty of the ruler and the necessity of obedience to him«, Burgess and Kulikowski, Historical Introduction, 199.

57 See RB and MK's brilliant passage beginning with: »The reader is still required to pick out and isolate the narrative ... the work is done by the reader, « Burgess and Kulikowski, Historical Introduction, 24.

58 Isidore initiates his discussion of chronica by claiming mimesis of one of RB and MK's paradigmatic chronicles, the Chronici Canones (or Chronica) of Eusebius of Caesarea: Apud Graecos Eusebius Caesariensis episcopus edidit, et Hieronymus presbyter in Latinam linguam convertit., Isidore of Seville, Etymologiae, ed. Lindsay, v.xviii.11-13 (»Among the Greeks Eusebius, Bishop of Caesarea, compiled such a work, and the priest Jerome translated it into Latin.", Isidore of Seville, Etymologies of Isidore of Seville, ed./trans. Barney et al., 125 col. B). RB and MK spend their third chapter painstakingly proving Eusebius' work was an >Ancient Greek Chronicler. See the key conclusions: Burgess and Kulikowski, Historical Introduction, 122-126.

59 Contra the conclusion that in the Etymologiae, Isidore only presents "a heavily compressed epitome of the later, longer version of the chronicle«, Burgess and Kulikowski, Historical Introduction, 199. 
Isidore's Chronica communicated something "new " and "useful " about the reckoning of time. There are good reasons why RB and MK do not spend a great deal of time with the version of the Chronica epitomized in Isidore's Etymologiae (ca. 628). As do all scholars, RB and MK privilege the two »full« versions of the Chronica (the first produced c. 615 under King Sisebut, and the second produced a decade later in c. 626 after King Suinthila's accession required an update), for undoubtedly these longer instantiations are the fuller textual artefacts. ${ }^{60}$ Nevertheless, based on my re-reading of Cicero and my incorporation of genre theory, I would argue that we should not build our analysis of the text on our reading of the Chronica so much as evidence for how it was read: Isidore himself analysed the generic category of chronica more extensively and comprehensively than any other early medieval author, and his framing of the Chronica within his Etymologiae is key material for a generic history. We must take this evidence seriously.

The most recent scholarly study of Isidore's Etymologiae (John Henderson's The Medieval World of Isidore of Seville) draws an entirely different conclusion from RB and MK as to what Isidore thought chronica did. To elucidate the key points, Henderson insists that the unusual and enigmatic nature of the Etymologiae makes it nigh on impossible to identify what the text communicated without paying careful attention to framing, order, and the context of particular discussions; we must embrace the Etymologiae's spectacular web of associative meanings, its tapestries of form and content. Thus we must first note that in the Etymologiae, we find that Isidore physically separated his discussion of texts governed by "narrative " (narratio) from his discussion of chronica, setting the former in Book I, the latter in Book V. Isidore's comments on narrative texts - "On Grammar" - concluded the first part of the Etymologiae's tripartite opening discourse on the trivium (a book was devoted to each of Grammar, Rhetoric, and Dialectic) with his explication of historia. To set up the concept's etymology, Isidore worked through the interplay between form and method. Historia was first an over-arching genre denoting all narrative accounts of past occurrences: "a narratio of deeds accomplished; through it what occurred in the past is sorted out. ${ }^{61}$ Isidore did not leave his discussion here (with historia indistinguishable from annales, for instance), but clarified historia's uniqueness through a further, methodological, distinction: how did works called historia "sort out " the past? From what sorts of things would an author construct and compose historiae? Historia (like annales) worked in years, but (unlike annales), a historia was constructed with a much more reliable epistemology: investigation of things seen. ${ }^{62}$ Having conjured up both form and method in his reader's mind, Isidore provided the central idea of historia:

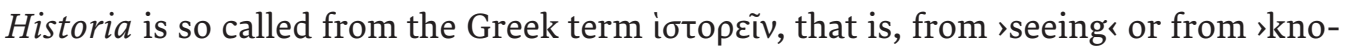
wing ‘... we grasp with our eyes things that occur better than what we gather from our hearing, since what is seen is revealed without falsehood. ${ }^{63}$

60 On the two versions, see Koon and Wood, Chronica Maiora, 3-5.

61 Isidore of Seville, Etymologies of Isidore of Seville, ed./trans. Barney, 67, col. A (Historia est narration rei gestae, per quam ea, quae in praeteritio facta sunt, dinoscuntur. Isidore of Seville, Etymologiae, ed. Lindsay, i.xli.18-19).

62 I have already noted RB and MK's directive to medievalists: cease using the term "annals" (n. 11, above). Isidore's distinction here is a counterpoint, though RB and MK are not the first to elide Isidore's comparisons between "historia«, "annales", and "chronica« (see: Deliyannis, Introduction, 3-6).

63 Isidore of Seville, Etymologies of Isidore of Seville, ed./trans. Barney et al., 67, col. A (Dicta autem Graece historia

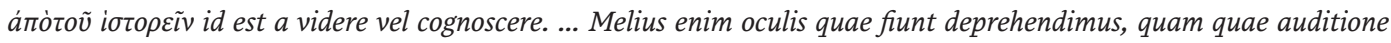
colligimus. Quae enim videntur, sine mendacio proferuntur. Isidore of Seville, Etymologiae, ed. Lindsay, i.xli.19-20, 22-24). 
And then Isidore again emphasized the point, this time with a comparison:

Historia is of those times that we have seen, but annals are of those years that our age has not known. ${ }^{64}$

Annales concerned themselves with the remote past and so had to be constructed using written records only. Historia worked with living memory. Historia alone both worked in the greatest unit of time (years), and relied on living memory to construct its account. ${ }^{65}$

By implication, if Isidore thought a narrative of the "six ages" governed chronica's logic, he would have categorized it under historia as a kind of annales, but Isidore did not. Instead, Isidore read chronica - still awaiting the reader to arrive in Book V, »On Laws and Times" to be ordered by a different rationale. What was that rationale? What was the form and the epistemology of a chronica? What did a chronica do? Isidore would brook no whiff of narratio in his explanation. Isidore's opening asserted that writing a chronica was primarily a kind of organization of the reckoning and periodization of time itself, an ordering of »the succession of times" (series temporum). ${ }^{66}$ Isidore explained that "times", here, denoted all measured lengths: from moments and hours, days and nights, to weeks, months, solstices, equinoxes, seasons, years, Olympiads, Jubilees, and finally to periods and ages (saecula et aetates) ${ }^{67}$ We must thus understand the abbreviated version of Isidore's own Chronica - the "epitome" provided at the end of Book $\mathrm{V}$ - as fulfilling these explanations: the division of time into ages stood upon the ordering of time from moment to moment. A chronica was not an account of the past, but the result of an organization, an ordering, of time itself. ${ }^{68}$

As Henderson points out, we must also bear in mind that - in the only such instance in the entire work - Isidore's reader was not told what »chronica " meant: his »epitome« of the Chronica replaced the expected etymology. Henderson guesses why: "This block of writing will consist of nothing but origins, since its dates all tell where a piece of the cultural encyclopedia came from, in telling us when it entered the archive. ${ }^{69}$ In other words: the "chronicle epitome« is the etymology, for Chronica provides the »etymology« for etymology itself. For Isidore, Chronica is the originary origin story. Chronica establishes the past into which narrative writes.

64 Isidore of Seville, Etymologies of Isidore of Seville, ed./trans. Barney et al., 67, col. B (Historia est eorum temporum quae vidimus, annales vero sunt eorum annorum quos aetas nostra non novit. Isidore of Seville, Etymologiae, ed. Lindsay, i.xliv.23-25).

65 Isidore of Seville, Etymologiae, ed. Lindsay, i.xliv.18-22. »Annales are the actions of individual years, for whatever domestic or military matters, on sea or land, are worthy of memory are treated year by year in records they called sannales from yearly deeds ... Annales are of those years that our age has not known.«, Isidore of Seville, Etymologies of Isidore of Seville, ed./trans. Barney et al., 67, col. B.

66 Isidore of Seville, Etymologiae, ed. Lindsay, v.xxviii.11.

67 Isidore of Seville, Etymologiae, ed. Lindsay, v.xxviii-xxxviii.

68 Bede's "Chronicle« is another example of the point, though scholars rarely dwell on the fact that Bede's "Chronicle« is Chapter 66 in a treatise on time's order (De Temporum Ratione): only after sixty-five chapters of instruction in the mechanics of temporal reckoning does Bede apply this reckoning to the writing of a chronica. See now: Palmer, Ends and Futures.

69 Henderson, Medieval World of Isidore of Seville, 93: "Here there will be never an etymology. Not one.« Neither does Isidore provide an exemplum of any other text type. 
If we recall Isidore's discussion of the division of time - from "second " to "age " - we might note that Isidore begins with the quantifiably measurable, and ends with the cultural-political: from "moment" to »historical period". Is this not evidence for RB and MK's position, that Isidore snuck narrative into time's structure? No, for by engaging directly with the implicit narrative of the idea of "ages", the Etymologiae unpacked an argument that sought to liberate time from the political, even as it pointed out the politics implicit in any reckoning of time. As Henderson shows, Isidore noted that Augustus Caesar had created the notion of an age, an epoch (»era") through a census that established itself as both date and fiscal deadline: "[Augustus] designated and dated his first tax assessment (census) as the year dot, for, in this epoch-making moment, legally/legibly >writing the Roman world meant sthe whole world contributing its earnings [aera] to the exchequer - hence the term serar [aes] $(5 \cdot 36.4) \cdot{ }^{70}$

Isidore's march through a chronographer's calculations proceeded unblinkingly from "material« to "political« reckoning. And not just any political, but the pan-cultural Mediterranean past of Roman Imperium. Isidore exposed the great temporal concept - the "age - as a homogenization of politics and past. This was an established fact, but Isidore wanted to say something yet more explicit. Again, I quote from Henderson's rendering of Isidore's critique:

Here is the point where Time must stand up to be counted, big time: aetas is indeed a concept, for this complex term homologizes, for a start, (its own) 3 dimensions, and then runs on, exponentially, ad infinitum - for "age« starts as the truly-reckoned lifespan of human, becomes humankind's reckoning of its "Ages«, but in its encompassing flexibility will then come to be eternity, where actual reckoning, and the story that is reckoned, come to the same thing. ${ }^{71}$

Isidore's reading of his own Chronica is on the same plane as the Ciceronian injunction we earlier proposed: to reveal time and so the world, anew. Time is not story, but it is a sort of writing. The Etymologiae proved that time is the writing of universe as law is the writing of society, that the reckoning of time »homologizes. « "Time, in this strange iconic writing stakes out, and narrates, the first six stages of human history in a distinctive idiom all of its own. « $^{72}$ That is, the textual logic (graphos) of a chronica was the order of events in time (chronos).

Why, then, did Isidore epitomize time into Christian ages if his true focus was the reckoning of time in se? Isidore's analysis and epitome laboured to show just how much the reckoning of time was, and is, political. The insight of the Chronica into the nature of reckoned or calculated time - "There is no record without regnum « ${ }^{73}$ - was a fundamentally postAugustan insight insofar as it was an insight that (chronologically speaking) Atticus could not have had: Augustus' imperious "homologizing " of time and empire had not yet occurred. Nevertheless, this does not, in my reading, taint it as a non-chronicle. Isidore's lesson, his Chronica's revelation, was that eternity (Henderson's »big time, « or time-as-such), would outshine empire (reckoned time). Reckoned time may be governed by empire and regnum, but big time "will out " (Henderson) in the literal sense that reckoned time will end, but big time - seternity` - will be.

70 Henderson, Medieval World of Isidore of Seville, 90.

71 Henderson, Medieval World of Isidore of Seville, 91.

72 Henderson italicizes narrates for reasons that should by now be clear, Henderson, Medieval World of Isidore of Seville, 93 .

73 Henderson, Medieval World of Isidore of Seville, 95. 
As Jamie Wood recently pointed out, the "murky circumstances" and outright "iniquitates" of the Visigothic successions from Sisibut to Suintila to Sisenand foreground the political and moral agenda of the bishop of Seville's historical writings. ${ }^{74}$ The Etymologiae lends itself to being read in light of at least as much political angst as enveloped Cicero's Brutus. In the Etymologiae's epitome, Isidore left a reading in nuce of his own Chronica, a "Ciceronian" unveiling which - for any reader willing to work it out for themselves - provided a message of comfort (salus) to all despairing of hope in political life. We cannot account for this message concerning the nature of reckoned time, and what political man should make of it, unless we allow this work to be grounded in time for a particularly contextualized readership. Isidore may have been an overly generous reader of his own text, but can we cannot ignore his precious account. Isidore read his own Chronica as a disruption of habituated thinking about time in the world, a disruption of accepted accounts of the nature of political time. Isidore read his Chronica as showing time within politics, and time outside of politics: an insight into time which Cicero would certainly have agreed was both new and useful for well-being.

\section{Conclusion: And if a work of art has no effect? Titles, and genres, and reading}

Historia, Annales, Chronica. These words are at once titles of works and names of perceived genres, and this conjunction makes these words matter a great deal. We often do not know what titles medieval authors gave to works, nor sometimes even the titles works circulated under. But every item needs a label, and so contemporary scholarly practice gives every work an ad hoc title-label identical with the work's imagined literary genre. These genres are, then, the ordered literary realms in which we understand ancient, ambiguous textual entities to function (or have functioned). Our title-label-genres thus construct an associative web of like-titled works and so reiterate the preconceived genre from which each title arose. And so, modern titles of medieval works are primarily a cue from Scholar $>X$, to Scholar,$Q$, of the genre in which we read Work >P ; t titles mark medievalists telling each other how to think about a work, and through this process we predetermine the comparative frame in which we read any text. Once a work has a title it is extremely difficult to sunthink « work from genre-title, especially acknowledging titles as established practices of scholarly reading: our understanding of `History«, `Annak, and `Chronicle have become the realms of possibility within which we permit works to matter.

It is not only possible, but needful, to work ourselves out of this constricting feedback loop. Medievalists have insisted to each other that we should think about (medieval) chronicles differently from shistory<, but how to do this at the level of genre has proven rather elusive. RB and MK's A Historical Introduction to the Chronicle Genre offers a significant step forward in this discussion and, as I have argued, by engaging with the authors' claims we can step even further. There is value in having more medievalists thinking about medieval chronicles as a genre stretching back into the ancient world, if only for the intellectual connections this would facilitate between scholars working on the innovative ways ancient authors portrayed their thinking about time, and knowledge. ${ }^{75}$

74 Wood, Politics of Identity, 74 and 144. Wood describes the relationship between Isidore's place in the political world of his day and the Etymologiae with such compelling comments as »the Etymologiae thus framed Isidore's entire project to position Visigothic Spain at the centre of the early medieval knowledge economy«, ibid., 77.

75 For instance: Lianeri, Western Time of Ancient History; König and Woolf, Encyclopedism from Antiquity. 
The stakes here are greater than field-specific. As we continue to wrestle with ideas like >Global and 'Deep< History, it would be worth reflecting on why, when our ancient and medieval cousins attempted parallel projects, they made a hard turn away from the investigative genre of historia; history-writing - whether ancient, late antique, early, central, or later medieval - limited itself to fields far smaller than the global. This is not to say that there were not attempts to encapsulate sthe world $<-$ a striking number of authors constructed a sbig past . But the great majority of ancient and medieval writers who considered human kind on a cosmological scale turned first to the issue of time, and produced chronica. Did Early Medieval authors realize that if they asked historia to contain the world, it would stretch and break? That the new wine would simply spill from the old skins? If nothing else, it seems appropriate to take a very critical look at the nature of our interest in sworlding s the past. If we search for sworld history « without truly reconsidering 'world times, are we pursuing a methodological non sequitur?

At the least, we must back away from our conceptual standoff with the past; as Burgess and Kulikowski have shown, we must stop reading chronicles as histories, and start reading chronicles as chronicles. By my reckoning, the way towards this end must now also embrace an understanding of genre more concerned with the effects a text had upon its contemporary readers. To do this, we cannot obscure the slim evidence we have for how rancient and smedieval< people thought about the works they read. We cannot abandon evidence of how - for instance - people like Isidore of Seville attempted to distinguish terms such as "annals", "history«, or »chronicle«.

The medievalist H. R. Jauss was quoted briefly above as expressing the concern that scholars see "the history of literary genres as a temporal process of the continual founding and altering of horizons", a history which possesses enough dynamism to incorporate works that would completely upset the generic expectations at any given time. Jauss claimed that any such expectation-upsetting work must not be seen as a failure to its own genre, but as a dynamic and ingenious

masterwork definable in terms of an alteration of the horizon of the genre that is as unexpected as it is enriching. ... [Masterworks] may change with the history of their effects and later interpretations, and thereby may also differently illuminate the coherence of the history of their genre that is to be narrated. ${ }^{76}$

Whether or not Jauss' term smasterwork is the most appropriate is not central to my point here. The point is rather Jauss' enthusiasm for scholars to adopt comparative approaches that truly and honestly incorporate the possibility of understanding difference as ingenious creativity.

Cicero's Brutus provided us with a proposition of the effect which a chronicle smasterwork might have been expected to produce: chronicles could offer a new encounter with time, an "alteration of the horizon«. Granting this, wouldn't we expect that, in order to continue making that same Ciceronian restoration-via-provocation, in order to translate the effect of the chronicle into new times and places, the tired, millennium-aged chronicle form would have to change? If a fundamental characteristic of a chronicle was to make a reader re-think their world by re-presenting time, would it not be necessary that five hundred years 
after Atticus' chronicle so surprised and delighted Cicero, a work seeking to portray time to the same effect would have to do so differently? Would the new, updated form not still be a schronicle for its own day? In short: instead of viewing Isidore's Chronica and other similar 'medievalı works as failures of the Ancient Greek Chronicle genre, should we not view them as Jauss-ian "masterworks" extending that powerful genre with Eusebian brilliance? Let us adopt RB and MK's account, but with the altered hypothesis that medieval chronographers updated chronicles to "new horizons". To provoke their readers to re-think time, successful chronicles re-invented the reckoning of time their readers took for granted. ${ }^{77}$ Chronicles - to re-deploy one of RB and MK's conclusions - "had evolved", and they were bound to keep evolving if only that they might persist in doing "their job «. ${ }^{78}$

\section{Acknowledgements:}

I would like to thank Kathryn Jasper for her immense help in honing the argument (such that it is) of this piece. Material support and an inspiring intellectual climate was provided by a faculty fellowship at the Center for Humanities at Wesleyan University.

77 As Bawarshi and Reiff propose (Genre, 21), we might understand genre as »a powerful, ideologically active, and historically changing shaper of texts, meanings, and social actions ... both organizing and generating kinds of texts and social actions, in complex, dynamic relation to one another."

78 Burgess and Kulikowski, Historical Introduction, 274. 


\section{References}

Bawarshi, Anis and Reiff, Mary Jo, Genre: An Introduction to History, Theory, Research, and Pedagogy (West Lafayette, 2012).

Burgess, Richard W. and Kulikowski, Michael, A Historical Introduction to the Chronicle Genre from its Origins to the High Middle Ages. Mosaics of Time: The Latin Chronicle Traditions from the First Century BC to the Sixth Century AD, vol. 1 (Turnhout, 2013).

Burgess, Richard W. and Kulikowski, Michael, Medieval Historiographical Terminology: The Meaning of the Word Annales, in: Erik Kooper and Sjoerd Levelt (eds.), The Medieval Chronicle VIII (Amsterdam, 2013) 165-192.

Burgess, Richard W. and Kulikowski, Michael, The History and Origin of the Latin Chronicle Tradition, in: Erik Kooper and Sjoerd Levelt (eds.), The Medieval Chronicle VI (Amsterdam, 2009) 153-178.

Chandler, Daniel, An Introduction to Genre Theory (1997, revised 2000). Retrieved on September 18, 2015: http://genreacrossborders.org/biblio/introduction-genre-theory.

Cicero, Brutus, ed. Henrica Malcovati, M. Tulli Ciceronis: Scripta quae manserunt omnia 4 (second edition), (Leipzig, 1970). English translation: George Lincoln Hendrickson, Cicero: Brutus, The Loeb Classical Library (Cambridge, 1962).

Deliyannis, Deborah M., Introduction, in: Deborah M. Deliyannis (ed.), Historiography in the Middle Ages (Leiden 2003) 1-13.

Duff, David, Modern Genre Theory (Harlow, 2000).

Frow, John, Genre: An Introduction (London, 2005).

Henderson, John, The Medieval World of Isidore of Seville: Truth from Words (Cambridge, 2007).

Isidore of Seville, Etymologiae, ed. Wallace M. Lindsay, Isidori Hispalensis Episcopi, Etymologiarum sive Originum, 2 vols. (Oxford, 1911).

Isidore of Seville, The Etymologies of Isidore of Seville, ed. and trans. Stephen A. Barney, Jennifer A. Beach, Oliver Berghoff and W. J. Lewis (Cambridge, 2006).

Jauss, Hans Robert, Theory of Genres and Medieval Literature, in: Duff, Modern Genre Theory, 127-147.

König, Jason and Woolf, Greg (eds.), Encyclopedism from Antiquity to the Renaissance (Cambridge, 2013).

Koon, Sam and Wood, Jamie, The Chronica Maiora of Isidore of Seville: An Introduction and Translation, e-Spania 6, December 2008. Retrieved on 21 March 2016: http://e-spania. revues.org/15552.

Lianeri, Alexandra (ed.), The Western Time of Ancient History: Historiographical Encounters with the Greek and Roman Pasts (Cambridge, 2011).

Palmer, James, The Ends and the Futures of Bede's `De Temporum Rationer, in: Faith Wallis and Peter Darby (eds.), Bede and the Future (Burlington, 2014) 139-160.

Todorov, Tzvetan, The Origin of Genres, in: Duff, Modern Genre Theory 193-209

White, Hayden, The Value of Narrativity in the Representation of Reality, Critical Inquiry 7.1 (1980) 5-27.

Wood, Jamie, The Politics of Identity in Visigothic Spain: Religion and Power in the Histories of Isidore of Seville (Leiden, 2012). 